\title{
Rhodium catalyzed hydroformylation of kaurane derivatives: A route to new diterpenes with potential bioactivity
}

\author{
Andreia F. Peixoto ${ }^{a}$, Daniela S. de Melo ${ }^{b}$, Tânia F. Fernandes ${ }^{a}$, Yuraima Fonseca ${ }^{\text {e }}$, \\ Elena V. Gusevskaya ${ }^{\mathrm{b}}$, Artur M.S. Silva ${ }^{\mathrm{c}}$, Ricardo R. Contreras ${ }^{\mathrm{d}}$, Marisela Reyes ${ }^{\mathrm{d}}$, \\ Alfredo Usubillagad ${ }^{d}$, Eduardo N. dos Santos ${ }^{\mathrm{b}, *}$, Mariette M. Pereira ${ }^{\mathrm{a}, * *}$, J. Carles Bayón ${ }^{\mathrm{e}, * * *}$ \\ a Departamento de Química, Universidade de Coimbra, 3049 Coimbra, Portugal

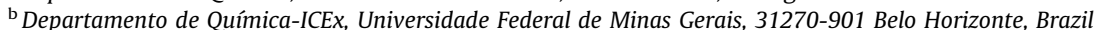 \\ ${ }^{\mathrm{c}}$ Departamento de Química, Universidade de Aveiro, 3810-193 Aveiro, Portugal \\ d Departamento de Química, Universidad de Los Andes, Mérida, Venezuela \\ ${ }^{\mathrm{e}}$ Universitat Autònoma de Barcelona, Bellaterra, 08193 Barcelona, Spain
}

\section{A R T I C L E I N F O}

\section{Article history:}

Received 9 January 2008

Received in revised form 12 February 2008

Accepted 13 February 2008

Available online 17 February 2008

\section{Keywords:}

Diterpenes

Kauranes

Hydroformylation

Rhodium

Phosphite

Phosphine

\begin{abstract}
A B S T R A C T
Kaurenic and grandiflorenic acids are naturally occurring diterpenes whose biological activity has been described. Both acids contain an exocyclic methylenic double bond that allows further functionalization on their structure. In an attempt to expand the number of derivatives of these two natural products, we have undertaken a study on the hydroformylation of the methyl esters of the two acids and the trimethylsilyl ether of kaurenol. These substrates have been hydroformylated by using unmodified $\mathrm{Rh}$ catalysts, as well as $\mathrm{Rh} / \mathrm{PPh}_{3}$ and $\mathrm{Rh} /$ tris-(o-t-butylphenyl)phosphite catalytic systems at $100{ }^{\circ} \mathrm{C}$ and 20 bar of $\mathrm{CO} / \mathrm{H}_{2}(1: 1)$. For the three substrates, the two Rh catalysts modified with P-donor ligands, produced high conversions and chemo- and regioselectivities in the diastereoisomeric pair of linear aldehydes. In all cases, the stereoselectivity observed is strongly dependent of the system used, being the most diastereoselective the least hindered unmodified $\mathrm{Rh} / \mathrm{CO}$ catalyst. A correlation between the higher diastereoselectivity and the faster $\beta$-elimination of the metal-alkyl intermediate observed in the unmodified system is discussed.
\end{abstract}

(c) 2008 Elsevier B.V. All rights reserved.

\section{Introduction}

Olefin hydroformylation (Oxo synthesis) is one of the most important industrial processes that employ transition metal catalysts in solution. The worldwide production of "Oxo" intermediates exceeds 6 million tons per year [1]. Although hydroformylation is mostly directed towards the transformation of simple olefins, in recent years this reaction has gathered importance in organic synthesis [2]. The most active catalysts are hydrido carbonyl complexes of cobalt and rhodium containing or not other ancillary ligands. For the applications in fine chemistry, rhodium catalysts are preferred in spite of their higher price, since they provide higher activity, better selectivity and

\footnotetext{
* Corresponding author. Tel.: +55 3134095743 .

** Corresponding author. Tel.: +35 1239854474

${ }^{* * *}$ Corresponding author. Tel.: +34 935812889 .

E-mail addresses: nicolau@ufmg.br (E.N. dos Santos),

mmpereira@qui.uc.pt (M.M. Pereira), joancarles.bayon@uab.es (J.C. Bayón).
}

usually require milder reaction conditions in comparison to the cobalt catalysts [3].

The hydroformylation of substrates containing disubstituted or endocyclic double bonds in an encumbered environment is troublesome, mostly because of steric reasons. The hydroformylation of such kind of substrates usually requires harsh reaction conditions for most of the catalysts [4]. Remarkable exceptions are rhodium(I) catalysts containing bulky phosphites, such as tris(o-tbutylphenyl)phosphite, $\mathrm{P}\left(\mathrm{O}-0-{ }^{t} \mathrm{BuC}_{6} \mathrm{H}_{4}\right)_{3}$ [5]. The large cone angle of this phosphite prevents the coordination of a second ligand to the metal centre, even when a large excess of phosphite is used. As a consequence, the overall steric hindrance around the rhodium centers is low compared to the ones containing two ligands, although the ligands may be individually less encumbered. Furthermore, this ligand has a weak $\sigma$-basicity combined with a strong $\pi$-acidity, which favours the CO dissociation and alkene coordination [6]. The Rh/tris(o-t-butylphenyl)phosphite catalytic system is used in the industrial hydroformylation of 3-methylbut3-en-1-ol [7]. Applications in the hydroformylation of other sterically hindered alkenes, such as cyclic ethers [8], glucal 
derivatives [9], fatty acids [10], terpenes [11] and steroids [12] have also been reported.

Kauranes are diterpenes with a rigid tetracyclic skeleton and are precursors of giberilines, a family of plant growth hormones. Kaurenic and grandiflorenic acids, $\mathbf{1}$ and 2, respectively in Scheme 1 , both containing a disubstituted double bond, are typical examples of this class of compounds. The concentration of kauranes is low in most plant species. Nevertheless, some plants of Espeletiinae family, such as "frailejón", a resinous plant native to the highlands ( páramos) of Venezuela and Colombia, contain a fair amount of both acids. Some species such as Espeletia semiglobulata Cuatrec present a high content of kaurenic acid $\mathbf{1}$ and kaurenol $\mathbf{2}$ [13]; while other, such as Espeletia schultzii Wedd, contain relatively high amounts of grandiflorenic acid $\mathbf{3}$ and lower concentrations of kaurenic acid [14].

Kaurenic acid is known to show an interesting biological activity, including anti-microbial, citotoxic, anti-inflammatory, and biocide properties [15]. One of its most interesting properties is the moderate in vitro activity against various lines of carcinogenic cells [16]. It has been reported that some kaurenic acid derivatives present a higher biological activity or a lesser toxic effect than the natural diterpene. For instance, the C16 oxime derivative shows an enhanced trypanocidal activity with respect to the natural diterpene, while the derivative produced via the substitution of the acid at $\mathrm{C} 1$ by the $\mathrm{N}$-pyrrolidinylmethyl group shows a similar trypanocidal activity, but a reduced lytic activity on blood erythrocytes in comparison to the unmodified terpene [17]. More recently, it has been demonstrated that the dihydroxylation at the double bond of kaurenic acid enhances its inhibitory activity against $\alpha$-glucosidase [18]. Therefore, the functionalization of the exocyclic double bond of these terpenes through hydroformylation is a relevant way of modifying their basic structures with the generation of new aldehydes. These aldehydes may be easily converted into other functional groups by classical organic reactions, which would open the possibility for the synthesis of a plethora of new derivatives.

We report herein the study of the rhodium-catalyzed hydroformylation of the methyl esters of kaurenic and grandiflorenic acids (1a and 3a, respectively), as well as the trimethylsilylether of kaurenol 2a (Scheme 1).

\section{Experimental}

\subsection{Materials}

Kaurenic acid and kaurenol were extracted from the aerial parts of Espeletia semiglobulata as described by Visbal et al. [19] and Bautista et al. [20], respectively. A mixture of grandiflorenic and kaurenic acids (77/23) was obtained from Espeletia schultzii as described by Ibañez [21]. The evaporated methanol and acetone extracts were purified by preparative column chromatography (silica, 70-230 mesh) and preparative TLC chromatography (silica, HF 254). The diterpenes were characterized by ${ }^{1} \mathrm{H}$ and ${ }^{13} \mathrm{C}$ NMR spectroscopy and GC-MS [19-21]. Tris(o-t-butylphenyl)phosphite was synthesized by a published method [5]. Toluene used in the catalytic experiments was purified by reflux over sodium lumps/ benzophenone for $8 \mathrm{~h}$ and then distilled under argon.

\subsection{Substrates derivatization}

\subsubsection{Synthesis of the methyl esters of kaurenic acid 1 a and grandiflorenic acid $3 a$}

A solution of $\mathrm{KOH}$ ( $1.0 \mathrm{~g}$ in $20 \mathrm{~mL}$ of a mixture of ethanol-water $(1 / 10))$ was added to a distillation flask fitted with a condenser containing a solution of Diazald $(5 \mathrm{~g})$ in ethyl ether $(50 \mathrm{~mL})$ [caution!]. The flask was heated to $65{ }^{\circ} \mathrm{C}$ in a water bath and the distilled diazomethane solution was directly poured into an ethereal solution of either kaurenic $\mathbf{1}$ or grandiflorenic acids $\mathbf{3}$ until this solution turned yellow. From these solutions, the methyl kaurenate 1a was obtained in $90 \%$ yield and the methyl grandiflorenate $\mathbf{3 a}$ in $85 \%$ yield, after purification through column chromatography (silica, dichloromethane).

Methyl kaurenate 1a. MS (EI $70 \mathrm{eV}): m / z=316\left(\mathrm{M}^{+\bullet}\right) ;{ }^{1} \mathrm{H}$ NMR $\left(\mathrm{CDCl}_{3}, 300 \mathrm{MHz}\right): \delta=0.83\left(\mathrm{~s}, 3 \mathrm{H}, \mathrm{CH}_{3}-20\right), 1.17\left(\mathrm{~s}, 3 \mathrm{H}, \mathrm{CH}_{3}-18\right)$, $3.64\left(\mathrm{~s}, 3 \mathrm{H}, \mathrm{COOCH}_{3}\right), 4.74$ and $4.80\left(2 \mathrm{br} \mathrm{d}, 2 \times 1 \mathrm{H}, \mathrm{CH}_{2}-17\right) ;{ }^{13} \mathrm{C}$ NMR: $\delta=40.7\left(\mathrm{CH}_{2}-1\right), 19.1\left(\mathrm{CH}_{2}-2\right), 38.1\left(\mathrm{CH}_{2}-3\right), 43.8(\mathrm{C}-4), 57.0$ (CH-5), $21.9\left(\mathrm{CH}_{2}-6\right), 41.3\left(\mathrm{CH}_{2}-7\right), 44.2(\mathrm{C}-8), 55.0(\mathrm{CH}-9), 39.4(\mathrm{C}-$ 10), $18.4\left(\mathrm{CH}_{2}-11\right), 33.1\left(\mathrm{CH}_{2}-12\right), 39.6\left(\mathrm{CH}_{2}-14\right), 48.9\left(\mathrm{CH}_{2}-15\right)$, 155.9 (C-16), 102.9 ( $\mathrm{CH}-17), 28.7\left(\mathrm{CH}_{3}-18\right), 178.1(\mathrm{C}-19), 15.4\left(\mathrm{CH}_{3}-\right.$ 20), $51.1\left(-\mathrm{OOCH}_{3}\right)$.

Methyl grandiflorenate 3a. MS (EI $70 \mathrm{eV}): m / z=314\left(\mathrm{M}^{+\bullet}\right) ;{ }^{1} \mathrm{H}$ NMR ( $\left.\mathrm{CDCl}_{3}, 300 \mathrm{MHz}\right): \delta=0.93\left(\mathrm{~s}, 3 \mathrm{H}, \mathrm{CH}_{3}-20\right), 1.18\left(\mathrm{~s}, 3 \mathrm{H}, \mathrm{CH}_{3}-\right.$ $18), 3.66\left(\mathrm{~s}, 3 \mathrm{H}, \mathrm{COOCH}_{3}\right), 4.80$ and $4.91\left(2 \mathrm{br} \mathrm{d}, 2 \times 1 \mathrm{H}, \mathrm{CH}_{2}-17\right)$, $5.23(\mathrm{t}, J=6.3 \mathrm{~Hz}, 1 \mathrm{H}, \mathrm{CH}-11) ;{ }^{13} \mathrm{C}$ NMR: $\delta=41.0\left(\mathrm{CH}_{2}-1\right), 18.8\left(\mathrm{CH}_{2}-\right.$ 2), $38.0\left(\mathrm{CH}_{2}-3\right), 43.9(\mathrm{C}-4), 49.6(\mathrm{CH}-5), 21.2\left(\mathrm{CH}_{2}-6\right), 41.4\left(\mathrm{CH}_{2}-7\right)$, 43.9 (C-8), 156.1 (C-9), 38.8 (C-10), $114.5(\mathrm{CH}-11), 34.0\left(\mathrm{CH}_{2}-12\right)$, 40.8 (CH-13), $39.2\left(\mathrm{CH}_{2}-14\right), 50.0\left(\mathrm{CH}_{2}-15\right), 155.9(\mathrm{C}-16), 103.8$ $\left(\mathrm{CH}_{2}-17\right), 28.1\left(\mathrm{CH}_{3}-18\right), 23.5\left(\mathrm{CH}_{3}-20\right), 51.3\left(-\mathrm{OOCH}_{3}\right), 155.91(\mathrm{C}-$ 16), 178.0 (C-19).

\subsubsection{Synthesis of trimethylsilylkaurenol ether $2 a$}

Under inert atmosphere, trimethylchlorosilane $(150 \mu \mathrm{L}$, $1.18 \mathrm{mmol}$ ) was added via syringe to a solution of kaurenol (288 $\mathrm{mg}, 1.00 \mathrm{mmol})$ and 1,4-diazobicyclo[2,2,2]octane (DBO) $(318 \mathrm{mg}, 2.83 \mathrm{mmol})$ in toluene $(10 \mathrm{~mL})$, with concomitant formation of white precipitate. In order to accomplish the reaction, after $2 \mathrm{~h}$, an additional $60 \%$ of trimethylchlorosilane $(90 \mu \mathrm{L}$, $0.71 \mathrm{mmol}$ ) was added. The reaction was monitored by TLC until complete consumption of kaurenol was observed. Then, the ammonium salt was filtered and the filtrate was concentrated to produce trimethylsilylkaurenol ether as a solid (354 $\mathrm{mg}, 98 \%$ yield). MS(EI): $m / z=360\left(\mathrm{M}^{+\bullet}\right) ;{ }^{1} \mathrm{H} \mathrm{NMR}\left(\mathrm{CDCl}_{3}, 300 \mathrm{MHz}\right): \delta=0.08(\mathrm{~s}, 9 \mathrm{H},-$ $\left.\mathrm{Si}\left(\mathrm{CH}_{3}\right)_{3}\right), 0.89$ (s, 3H, $\left.\mathrm{CH}_{3}-20\right), 0.99\left(\mathrm{~s}, 3 \mathrm{H}, \mathrm{CH}_{3}-18\right), 4.73$ and $4.79(2$ br d, $\left.2 \times 1 \mathrm{H}, \mathrm{CH}_{2}-17\right) ;{ }^{13} \mathrm{C}$ NMR: $\delta=39.7\left(\mathrm{CH}_{2}-1\right), 18.4\left(\mathrm{CH}_{2}-2\right), 38.6$ $\left(\mathrm{CH}_{2}-3\right), 44.2(\mathrm{C}-4), 56.7(\mathrm{CH}-5), 20.3\left(\mathrm{CH}_{2}-6\right), 40.5\left(\mathrm{CH}_{2}-7\right), 44.0$ (C-8), 56.2 (CH-9), 39.2 (C-10), $18.2\left(\mathrm{CH}_{2}-11\right), 33.2\left(\mathrm{CH}_{2}-12\right), 41.7$
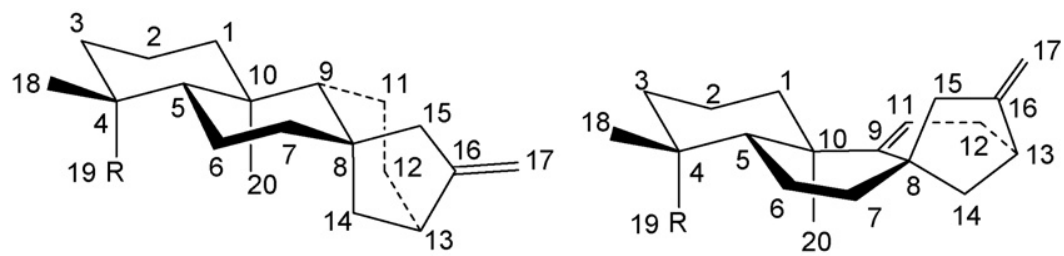

$$
\begin{array}{ll}
1 \mathrm{R}=\mathrm{CO}_{2} \mathrm{H} & \text { 1a } \mathrm{R}=\mathrm{CO}_{2} \mathrm{Me} \\
2 \mathrm{R}=\mathrm{CH}_{2} \mathrm{OH} & \text { 2a } \mathrm{R}=\mathrm{CH}_{2} \mathrm{OSiMe}_{3}
\end{array}
$$

$$
3 \mathrm{R}=\mathrm{CO}_{2} \mathrm{H} \quad 3 \mathrm{a} \mathrm{R}=\mathrm{CO}_{2} \mathrm{Me}
$$

Scheme 1. 
( $\left.\mathrm{CH}_{2}-13\right), 35.5\left(\mathrm{CH}_{2}-14\right), 49.1\left(\mathrm{CH}_{2}-15\right), 156.0(\mathrm{C}-16), 102.9\left(\mathrm{CH}_{2}-17\right)$, $27.6\left(\mathrm{CH}_{3}-18\right), 64.4\left(\mathrm{CH}_{2}-19\right), 18.1\left(\mathrm{CH}_{3}-20\right), 1.9\left(-\mathrm{Si}\left(\mathrm{CH}_{3}\right)_{3}\right)$.

\subsection{Catalytic experiments}

The catalyst $\left[\mathrm{Rh}(\mathrm{acac})(\mathrm{CO})_{2}\right]\left(2.8 \times 10^{-3} \mathrm{mM}\right)$ with or without the desired P-donor ligand were placed in a glass-lined stainless steal autoclave, which was closed and purged with three cycles of vacuum and a $\mathrm{CO} / \mathrm{H}_{2}$ equimolar mixture. Then, toluene $(4 \mathrm{~mL})$ was cannuled under vacuum and the autoclave was pressurized to 40 bar with an $\mathrm{CO} / \mathrm{H}_{2}$ equimolar mixture and heated at $100{ }^{\circ} \mathrm{C}$ for $45 \mathrm{~min}$. After this time, the autoclave was cooled and slowly depressurized. A solution of the desired substrate $(0.14 \mathrm{mmol}$ in $4 \mathrm{~mL}$ of toluene) was added via cannula into the autoclave which was pressurized again to 20 bar with an $\mathrm{CO} / \mathrm{H}_{2}$ equimolar mixture and then heated at $100{ }^{\circ} \mathrm{C}$. Aliquots were taken periodically through a valve dip tube and analyzed by GC (HP 5890 instrument fitted with a HP5 capillary column and a FID detector) for controlling experiments. For preparative experiments, the catalytic reaction was stopped after $20 \mathrm{~h}$, and the aldehydes were isolated by preparative column chromatography (silica, dichloromethane) and analyzed by GC-MS (GC-MS was carried out on HP-5973 mass selective detector apparatus, equipped with capillary HP5 columns) and ${ }^{1} \mathrm{H}$ and ${ }^{13} \mathrm{C}$ NMR (Bruker 300 and $500 \mathrm{MHz}$ instruments). Assignments of the structure were made by 2D gCOSY and NOESY experiments for ${ }^{1} \mathrm{H}$ and 2D gHSQC and gHMBC experiments for ${ }^{13} \mathrm{C}$ (long-range $\mathrm{C} / \mathrm{H}$ coupling constants optimized for $7 \mathrm{~Hz}$ ) and are presented below.

\subsection{Aldehydes characterization}

Aldehydes 1c and 1d: The purified mixture of aldehydes was isolated as a solid ( $28.7 \mathrm{mg}, 65 \%$ yield) from the hydroformylation of $1 \mathrm{a}$, by using $\mathrm{Rh} / \mathrm{P}\left(\mathrm{O}-{ }^{-}-{ }^{\mathrm{t}} \mathrm{BuC}_{6} \mathrm{H}_{4}\right)_{3}$ as catalyst, as described above. MS(EI) for 1c: $(\mathrm{m} / \mathrm{z})$ : $346\left(\mathrm{M}^{+\bullet}\right) ;{ }^{1} \mathrm{H}$ and ${ }^{13} \mathrm{C}$ NMR are collected in Tables 1 and 2.

Aldehydes 2c and 2d: the purified mixture of aldehydes was isolated as a solid ( $39.3 \mathrm{mg}, 78 \%$ yield) from the hydroformylation of 2a, by using $\mathrm{Rh} / \mathrm{P}\left(\mathrm{O}-{ }^{-}-{ }^{\mathrm{t}} \mathrm{BuC}_{6} \mathrm{H}_{4}\right)_{3}$ as catalyst. $\mathrm{MS}(\mathrm{EI}) \mathbf{2 c}$ : $(\mathrm{m} / \mathrm{z})$ : $390\left(\mathrm{M}^{+\bullet}\right) ;{ }^{1} \mathrm{H}$ and ${ }^{13} \mathrm{C}$ NMR are collected in Tables 1 and 2.
Aldehydes 3c and 3d: the purified mixture of aldehydes was isolated as a solid ( $23.4 \mathrm{mg}, 63 \%$ yield) from the hydroformylation of a mixture 3a and 1a $(77 / 23)$, by using $\mathrm{Rh} / \mathrm{P}\left(\mathrm{O}-{ }_{-0}{ }^{\mathrm{t}} \mathrm{BuC}_{6} \mathrm{H}_{4}\right)_{3}$ as catalyst. MS(EI) for 3c: $(\mathrm{m} / \mathrm{z} /): 344\left(\mathrm{M}^{+\bullet}\right) .{ }^{1} \mathrm{H}$ and ${ }^{13} \mathrm{C}$ NMR data are collected in Tables 1 and 2 .

\section{Results and discussion}

The hydroformylation of substrates $\mathbf{1 a}, \mathbf{2 a}$ and $\mathbf{3 a}$ was investigated with three different catalytic systems: the unmodified Rh catalyst ( $\mathrm{Rh} / \mathrm{CO})$, the $\mathrm{Rh}$ modified with tris(o-t-butylphenyl)phosphite $\left(\mathrm{Rh} / \mathrm{P}\left(\mathrm{O}-\mathrm{O}-{ }^{\mathrm{t}} \mathrm{BuC}_{6} \mathrm{H}_{4}\right)_{3}\right)$, and the $\mathrm{Rh}$ modified with triphenylphosphine $\left(\mathrm{Rh} / \mathrm{PPh}_{3}\right)$. [Rh(acac $\left.)(\mathrm{CO})_{2}\right]$ was always used as the catalyst precursor in a molar ratio substrate $/ \mathrm{Rh}=50$. For the two modified catalytic systems, a molar ratio $\mathrm{P}$-donor $/ \mathrm{Rh}=15$ was employed in order to ensure that a unique sterical hindered catalytic active species $\left(\mathrm{RhH}(\mathrm{CO})_{2}\left(\mathrm{P}\left(\mathrm{O}-\mathrm{o}-{ }^{\mathrm{t}} \mathrm{BuC}_{6} \mathrm{H}_{4}\right)_{3}\right.\right.$ and $\mathrm{RhH}(\mathrm{CO})\left(\mathrm{PPh}_{3}\right)_{2}$, respectively) is formed [2].

For the hydroformylation of methyl kaurenate $\mathbf{1 a}$, the three catalytic systems yielded the diasteroisomeric aldehydes $1 \mathbf{c}$ and $\mathbf{1 d}$ and the isomerization product $\mathbf{1 b}$. Analogously, trimethylsylilkaurenol ether $\mathbf{2 a}$ produced the aldehydes $\mathbf{2 c}$ and $\mathbf{2 d}$, as well as the isomerization product $\mathbf{2 b}$ (Scheme 2 ). Only small amounts ( $<2 \%$ ) of the alkene hydrogenation products were detected in all cases. Very minor amounts, if any at all, of other aldehydes were observed by GC. Therefore, for both substrates the reaction is highly regioselective for the formation of the linear aldehydes under the conditions employed.

The aldehydes 1c and 1d were identified by their molecular ions $(m / z=346)$ in the mass spectra, as well as by the characteristic aldehydic protons in the ${ }^{1} \mathrm{H}$ NMR spectrum obtained from a mixture of 1c/1d that showed a triplet $\left({ }^{3} J=2.0 \mathrm{~Hz}\right)$ at $\delta 9.78 \mathrm{ppm}$ for the major aldehyde 1c, and a second triplet $\left({ }^{3} \mathrm{~J}=1.9 \mathrm{~Hz}\right)$ at $\delta$ $9.72 \mathrm{ppm}$ for the minor aldehyde $\mathbf{1 d}$. The appearance of two triplet signals indicates that both aldehydes are the linear isomers arising from the anti-Markovnikov addition of the formyl group and hydrogen to the double bond from both diasterotopic faces. Similarly, a mixture of aldehydes isolated after the hydroformylation of $\mathbf{2 a}$ showed a signal at $\delta 9.78 \mathrm{ppm}$ for the major aldehyde $\mathbf{2 c}$, and a second signal at $\delta 9.71 \mathrm{ppm}$ for the minor aldehyde $\mathbf{2 d}$. This

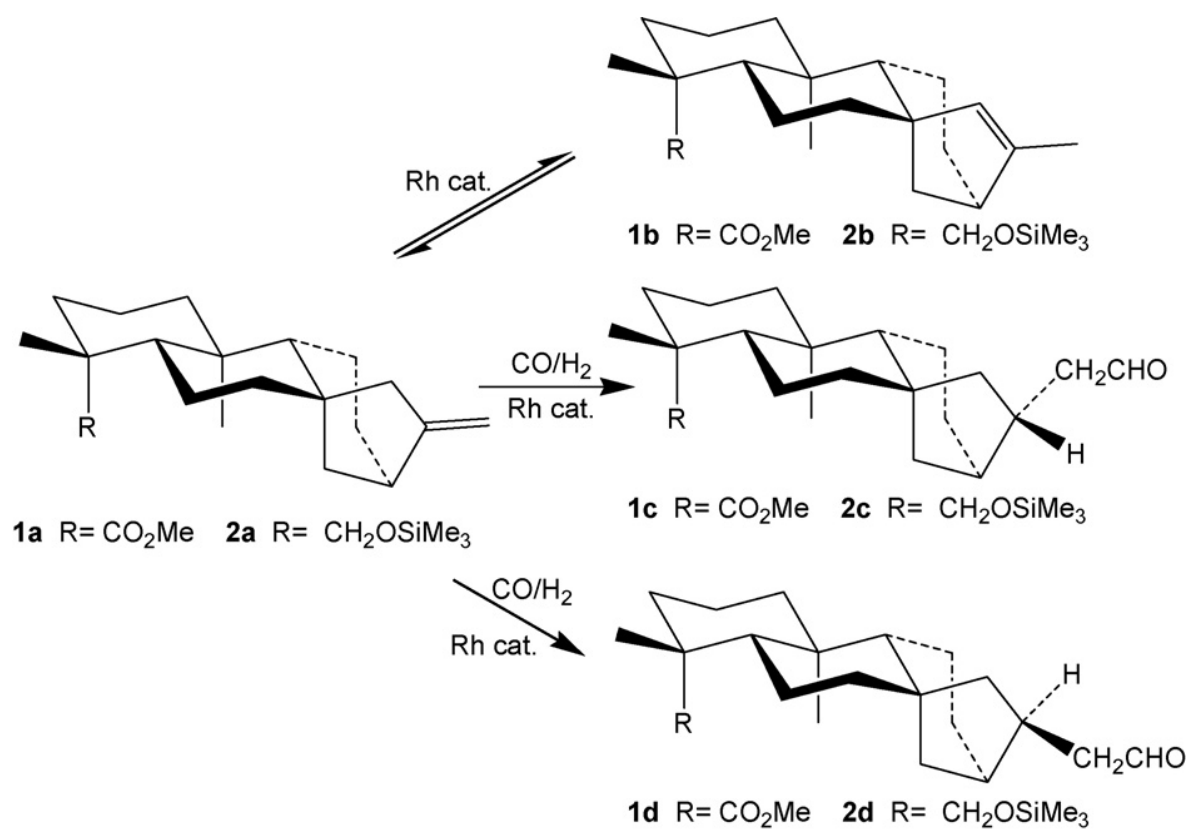

Scheme 2. 
Table 1

${ }^{1} \mathrm{H}$ NMR assignments (ppm) of aldehydes $\mathbf{1 c}, \mathbf{2 c}$ and $\mathbf{3 c}$

\begin{tabular}{|c|c|c|c|}
\hline & $1 \mathrm{c}$ & $2 \mathrm{c}$ & $3 c$ \\
\hline $\mathrm{H} 1$ & $1.78-1.85$ & $0.75-0.85$ and $1.80-1.85$ & $1.17-1.25$ and $1.89-1.95$ \\
\hline H3 & $0.92-0.99$ and $2.13-2.18$ & $0.98-1.08$ and $1.89-1.99$ & $0.99-1.08$ and $2.12-2.19$ \\
\hline H5 & $0.99-1.06$ & $0.95-1.10$ & $1.65(\mathrm{dd}, J=8.4$ and $10.8 \mathrm{~Hz})$ \\
\hline H9 & $0.98-0.99$ & $0.95-1.10$ & - \\
\hline H11 & $1.56-1.61$ & $1.52-1.62$ & $5.23(\mathrm{t}, J=3.3 \mathrm{~Hz})$ \\
\hline $\mathrm{H} 12$ & $1.45-1.50$ & $1.48-1.61$ & $1.95-2.03$ and $2.29-2.38$ \\
\hline H13 & $1.83-1.92$ & $1.83-1.92$ & $1.89-1.92$ \\
\hline $\mathrm{H} 14$ & $1.00-1.09$ and $1.78-1.87$ & $0.90-0.95$ and $1.73-1.84$ & $0.99-1.07$ and $2.29-2.37$ \\
\hline H15 & $0.87-0.93$ and $1.69-1.77$ & $0.88-0.95$ and $1.70-1.81$ & - \\
\hline H16 & $2.25-2.33$ & $2.24-2.28$ and $2.40-2.46$ & $2.29-2.34$ \\
\hline $\mathrm{H} 17$ & $2.37-2.43$ & $2.37-2.42$ & $2.42-2.52$ \\
\hline H18 & 1.16 & 0.98 & 1.17 \\
\hline H19 & - & 3.44 and $3.74(2 \mathrm{~d}, J=10.9 \mathrm{~Hz})$ & - \\
\hline $\mathrm{H} 20$ & 0.80 & 0.95 & 0.91 \\
\hline $\mathrm{CHO}$ & $9.72(\mathrm{t}, J=1.9 \mathrm{~Hz})$ & $9.71(\mathrm{t}, J=1.9 \mathrm{~Hz})$ & $9.73(\mathrm{t}, J=1.9 \mathrm{~Hz})$ \\
\hline $\mathrm{COOCH}_{3}$ & 3.64 & - & 3.65 \\
\hline $\mathrm{Si}\left(\mathrm{CH}_{3}\right)_{3}$ & - & 0.07 & - \\
\hline
\end{tabular}

also indicates the formation of a distereoisomeric pair of linear aldehydes. For both couples of aldehydes, the $\mathbf{1 c} / \mathbf{1 d}$ and $\mathbf{2 c} / \mathbf{2 d}$ ratios calculated from integration of their ${ }^{1} \mathrm{H}$ NMR signals in the crude reaction mixture were in agreement with the ratios obtained from the integration of the respective GC peaks.

The ${ }^{1} \mathrm{H}$ and ${ }^{13} \mathrm{C}$ NMR analysis (COSY, HMBC and HSQC spectra) of the two mixtures of aldehydes arising from $\mathbf{1 a}$ and $\mathbf{2 a}$ allowed the assignment of most of the proton and carbon resonances for the major aldehydes in each mixture, 1c and 2c. These results are collected in Tables 1 and 2.

The stereochemistry of the major aldehydes 1c and 2c was determined by NOESY 2D NMR. Strong correlations were observed between the $\mathrm{CHO}$ group and $\mathrm{H} 13$ and $\mathrm{H} 16$, as well as the expected one with $\alpha$-carbonyl methylenic protons. These allowed corroborating the previously assigned signals for $\mathrm{H} 13$ and H16. The crucial correlation to determine the configuration of $1 \mathbf{c}$ and $2 \mathbf{c}$ was the one between $\mathrm{H} 13$ and $\mathrm{H} 16$. This is consistent with a cis arrangement for these protons as shown in Scheme 3.

The stereochemistry of the major aldehydes $\mathbf{1 c}$ and $\mathbf{2 c}$ indicates that the substrate coordination to the rhodium hydride species

Table 2

${ }^{13} \mathrm{C}$ NMR assignments (ppm) of aldehydes 1c, $2 \mathrm{c}$ and $\mathbf{3 c}$

\begin{tabular}{lccr}
\hline & 1c & 2c & 3c \\
\hline $\mathrm{C} 1$ & 40.7 & 39.1 & 41.0 \\
$\mathrm{C} 2$ & 19.1 & 18.5 & 18.5 \\
$\mathrm{C} 3$ & 38.0 & 37.1 & 38.4 \\
$\mathrm{C} 4$ & 43.7 & 46.0 & 44.8 \\
$\mathrm{C} 5$ & 56.9 & 56.7 & 46.6 \\
$\mathrm{C} 6$ & 22.4 & 20.9 & 20.2 \\
$\mathrm{C} 7$ & 41.6 & 40.4 & 42.4 \\
$\mathrm{C} 8$ & 45.5 & 45.4 & 43.5 \\
$\mathrm{C} 9$ & 55.1 & 56.2 & 156.1 \\
$\mathrm{C} 10$ & 39.3 & 38.6 & 38.6 \\
$\mathrm{C} 11$ & 18.7 & 18.2 & 114.5 \\
$\mathrm{C} 12$ & 31.1 & 31.2 & 37.0 \\
$\mathrm{C} 13$ & 41.7 & 41.9 & 39.4 \\
$\mathrm{C} 14$ & 37.1 & 35.5 & 29.8 \\
$\mathrm{C} 15$ & 48.8 & 48.8 & 50.9 \\
$\mathrm{C} 16$ & 34.3 & 34.4 & 39.2 \\
$\mathrm{C} 17$ & 52.0 & 52.0 & 51.8 \\
$\mathrm{C} 18$ & 28.7 & 27.0 & 28.1 \\
$\mathrm{C} 19\left(\mathrm{CO}_{2} \mathrm{Me}\right)$ & 178.1 & - & 178.0 \\
$\mathrm{C} 19\left(\mathrm{CH}_{2}-\mathrm{Si}\right)$ & - & 65.5 & - \\
$\mathrm{C} 20$ & 15.3 & 18.1 & 23.5 \\
$\mathrm{CHO}$ & 203.0 & 203.0 & 202.8 \\
$\mathrm{COOCH}$ & - & 1.91 & 51.3 \\
$\left.\mathrm{Si}(\mathrm{CH})_{3}\right)_{3}$ & 51.1 & & - \\
\hline $\mathrm{T} 12 \mathrm{rem}_{2}$ & - & - &
\end{tabular}

The remained ${ }^{13} \mathrm{C}$ NMR resonances were not assigned. takes place preferentially through the less hindered face of the double bond. The stiff four ring fused systems of the substrates 1a and 2a lead to structures with a deep energy conformational minimum. The rigidity of these structures is even higher in the double bond domain, because of the reduced conformational mobility of the five-membered fused ring. Furthermore, the topologies on double bond domains are very similar for both substrates. Because of the rigidity of these substrates, the formation of the two linear alkyl intermediates should be mainly controlled by the steric hindrance of the two diastereotopic faces of the double bond (i.e. the transition states leading to the alkyl intermediates are substrate-like). This is illustrated in Scheme 4, which shows that the approach of the catalyst through the top face of the double bond is hindered by the axial H11, which is perpendicular with respect to the plane containing the $\mathrm{sp}^{2}$ orbitals of the double bond, while the approach through the bottom face is less encumbered. Therefore, the configuration of the major aldehydes 1c and 2c can be rationalized through the difference between the steric accessibility of the two faces of the double bond. The specific stereochemical outcome of each catalytic reaction will depend on the small differences of each substrate in the accessibility of the diasterotopic faces, as well as on the steric hindrance of the catalyst [22].

A third factor that must be taken into account, although its influence in the diasteroselectivity is not straightforward, is the $\beta$ elimination in the alkyl intermediates formed by the insertion of the alkene into the metal-hydride bond [23]. For the linear metalalkyl intermediates the only possible product of the $\beta$-elimination is the substract itself, giving rise to an unproductive catalytic cycle. Nevertheless, the rates of $\beta$-elimination may be different for the different diasteroisomeric metal-alkyl intermediates and this will influence the stereochemical outcome for the aldehydes (due to the withdrawal of the common intermediate for $\beta$-elimination and hydroformylation) in a way not predictable by the steric

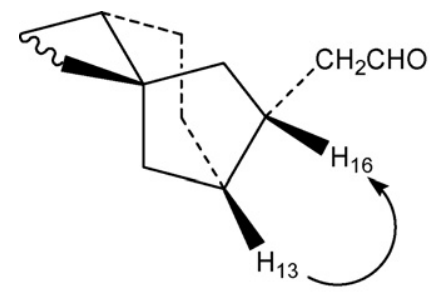

$1 \mathrm{c}$ and $2 \mathrm{c}$

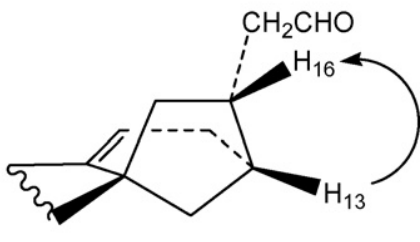

$3 c$
Scheme 3. Relevant NOE cross peaks observed in the NOESY spectra of $\mathbf{1 c}, \mathbf{2 c}$ and $\mathbf{3 c}$. 


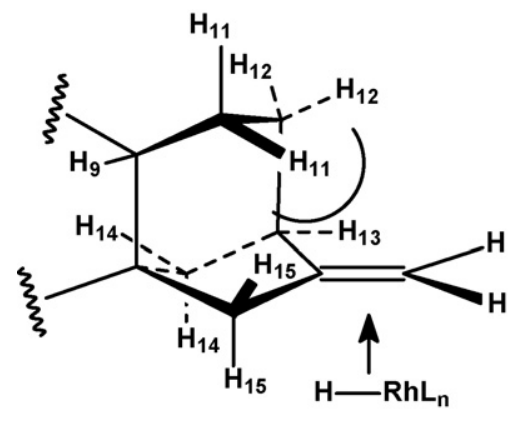

substrates $1 \mathrm{a}$ and $2 \mathrm{a}$

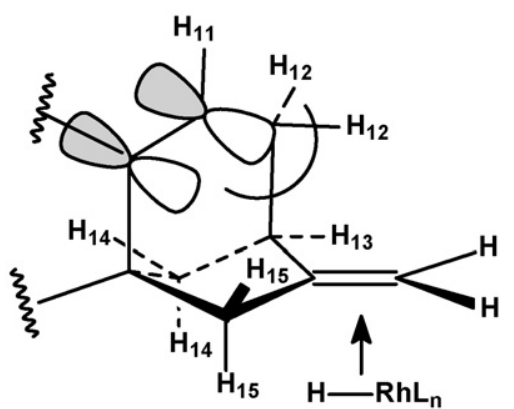

substrates $3 a$

Scheme 4

arguments presented above [24]. The last factor is probably not relevant for the systems with low tendency to produce $\beta$ elimination (e.g. $\mathrm{Rh} / \mathrm{PPh}_{3}$ ), but may play a decisive role for unmodified or phosphite-modified catalytic systems, in which the $\beta$-elimination is relevant [25-27].

Again, in the case of the methyl grandiflorenate $\mathbf{3 a}$, regardless of the catalyst used, the three main reaction products were the aldehydes $\mathbf{3 c}$ and $\mathbf{3 d}$ and the isomerization product $\mathbf{3 b}$ (Scheme 5). The hydrogenation product was detected only in small amounts $(<2 \%)$ in some reactions. Therefore, the hydroformylation of $\mathbf{3 a}$ is regiospecific for the exocyclic double bond and, furthermore, only linear aldehydes are formed, as in the case of $\mathbf{1 a}$ and $\mathbf{2} \mathbf{b}$.

The aldehydes $\mathbf{3 c}$ and $\mathbf{3 d}$ were identified by their molecular ions $(m / z=344)$ in the mass spectra, as well as by the characteristic aldehydic protons in the ${ }^{1} \mathrm{H}$ NMR spectrum obtained from a mixture of $3 \mathbf{c} / \mathbf{3 d}$ that showed a triplet $\left({ }^{3} \mathrm{~J}=1.8 \mathrm{~Hz}\right)$ at $\delta 9.78 \mathrm{ppm}$ for the major aldehyde $3 \mathbf{c}$, and a second triplet $\left({ }^{3} \mathrm{~J}=1.9 \mathrm{~Hz}\right)$ at $\delta$ $9.73 \mathrm{ppm}$ for the minor aldehyde $3 \mathbf{d}$. The pattern of the two signals indicates that these aldehydes arose exclusively from the antiMarkovnikov addition of the hydrogen and formyl group to the exocyclic double bond. This was further corroborated by the chemical shifts of the remainder olefinic carbons, C9 and C11, in the ${ }^{13} \mathrm{C}$ NMR spectrum of the aldehydes that were nearly identical to those of the substrate. Since in this case a complete separation of the GC peaks of the reaction products was not attained, the diasteroroselectivity of the reaction was calculated from the integration of the proton signals of the two aldehydes (Table 3).

The stereochemistry of $\mathbf{3 c}$, the major aldehyde resulted from the hydroformylation of methyl grandiflorenate $\mathbf{3 a}$, was also determined by a NOESY analysis. This showed a strong correlation peak between $\mathrm{H} 13$ and $\mathrm{H} 16$ indicating again a cis disposition for these two protons (Scheme 3). The result reveals that, also in this case, the syn hydrogen and formyl addition takes place through the less hindered face of the disubstituted double bond. In steric terms, the situation of this double bond is similar to those of kaurene derivatives 1a and 2a (Scheme 4). The main difference is that for 3a the top access to the double bond is hindered by the $\pi$ cloud of the endocyclic double bond, instead of the axial H11 already described in the case of 1a and 2a.

The three catalytic systems used for the hydroformylation of substrates 1a, 2a and 3a, working under the same reaction conditions ( $2 \% \mathrm{~mol} \mathrm{Rh,} 20$ bar of syn-gas and $100{ }^{\circ} \mathrm{C}$ ), showed important differences both in activity and selectivity (chemo and diastero) for the three substrates. The results of the catalytic runs are collected in Table 3 and the product evolution as a function of time is presented in Fig. 1, for the hydroformylation of 1a, in Fig. 2 for the hydroformylation of $\mathbf{2 a}$ and in Fig. 3 for the hydroformylation of $3 a$.

For substrate 1a, after $2 \mathrm{~h}$, the three catalytic systems showed conversions ranging between 64 and $82 \%$. However, in the absence

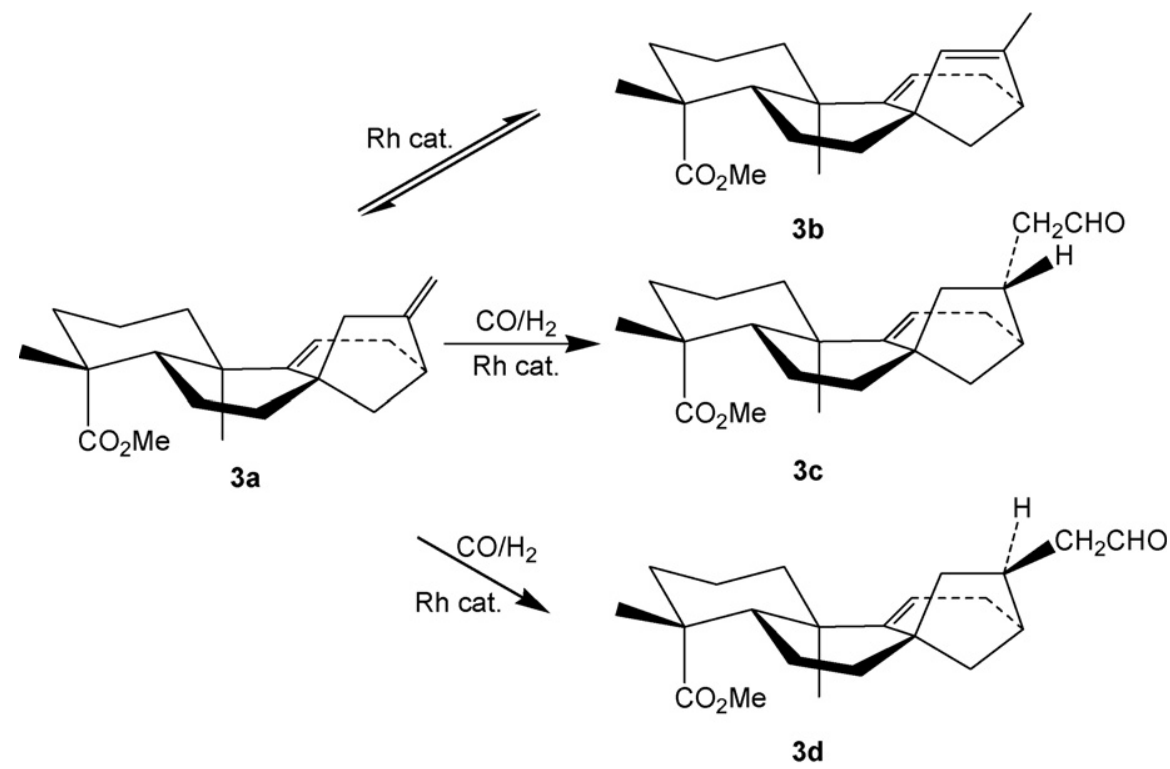

Scheme 5 . 
Table 3

Hydroformylation of substrates 1a, 2a and 3a with different Rh catalysts ${ }^{\mathrm{a}}$

\begin{tabular}{|c|c|c|c|c|c|c|}
\hline \multirow[t]{3}{*}{ Substrate } & \multirow[t]{3}{*}{ P-donor $^{\text {b }}$} & \multirow{2}{*}{\multicolumn{2}{|c|}{$\begin{array}{l}\text { Conversion } \\
(\%)^{c} \\
\text { Time (h) }\end{array}$}} & \multicolumn{2}{|c|}{$\begin{array}{l}\text { Selectivity to } \\
\text { aldehydes (\%) }^{\text {d }}\end{array}$} & \multirow[t]{3}{*}{$c / d^{e}$} \\
\hline & & & & \multirow[b]{2}{*}{2} & \multirow[b]{2}{*}{20} & \\
\hline & & 2 & 20 & & & \\
\hline $1 \mathbf{a}$ & None & 64 & 76 & 44 & 71 & $81 / 19$ \\
\hline $1 \mathbf{a}$ & $\mathrm{P}\left(\mathrm{O}-\mathrm{O}-{ }^{\mathrm{t}} \mathrm{BuC}_{6} \mathrm{H}_{4}\right)_{3}$ & 81 & 83 & 73 & 93 & $73 / 27$ \\
\hline $1 \mathbf{a}$ & $\mathrm{PPh}_{3}$ & 82 & 84 & 89 & 90 & $66 / 34$ \\
\hline $2 \mathbf{a}$ & None & 77 & 91 & 57 & 85 & $74 / 26$ \\
\hline $2 a$ & $\mathrm{P}\left(\mathrm{O}-\mathrm{O}-{ }^{\mathrm{t}} \mathrm{BuC}_{6} \mathrm{H}_{4}\right)_{3}$ & 90 & 92 & 88 & 96 & $70 / 30$ \\
\hline $2 a$ & $\mathrm{PPh}_{3}$ & 66 & 96 & 92 & 97 & $57 / 43$ \\
\hline $3 \mathbf{a}$ & None & 69 & 89 & 68 & 98 & $77 / 23$ \\
\hline $3 \mathbf{a}$ & $\mathrm{P}\left(\mathrm{O}-\mathrm{O}-{ }^{\mathrm{t}} \mathrm{BuC}_{6} \mathrm{H}_{4}\right)_{3}$ & 91 & 96 & 92 & 99 & $68 / 32$ \\
\hline $3 \mathbf{a}$ & $\mathrm{PPh}_{3}$ & 82 & 99 & 95 & 98 & $71 / 29$ \\
\hline
\end{tabular}

a Reaction conditions: $2.8 \times 10^{-3} \mathrm{mmol}$ of $\mathrm{Rh}$ as $\left[\mathrm{Rh}(\mathrm{acac})(\mathrm{CO})_{2}\right]$ and $0.14 \mathrm{mmo}$ of substrate in $8 \mathrm{~mL}$ of toluene; $P=20$ bar, $\mathrm{P}(\mathrm{CO})=\mathrm{P}\left(\mathrm{H}_{2}\right) ; T=100{ }^{\circ} \mathrm{C}$.

b $\mathrm{P}\left(\mathrm{O}-\mathrm{o}^{\mathrm{t}}{ }^{\mathrm{BuC}} \mathrm{Bu}_{6} \mathrm{H}_{3}\right.$ is tris-(o-t-butylphenyl)phosphite; $4.2 \times 10^{-2} \mathrm{mmol}$ of $\mathrm{P}(\mathrm{O}$ $\left.{ }_{0}-{ }^{\mathrm{t}} \mathrm{BuC}_{6} \mathrm{H}_{4}\right)_{3}$ added, $\left[\mathrm{P}\left(\mathrm{O}-\mathrm{o}-{ }^{\mathrm{t}} \mathrm{BuC}_{6} \mathrm{H}_{4}\right)_{3}\right] /[\mathrm{Rh}]=15 ; 4.2 \times 10^{-2} \mathrm{mmol}$ of $\mathrm{PPh}_{3}$ added, $\left[\mathrm{PPh}_{3}\right] /[\mathrm{Rh}]=15$

c Total amount of substrate converted after 2 and $20 \mathrm{~h}$ reaction.

d Chemoselectivity (\%) in aldehydes c plus d (see Schemes 1 and 2), with respect to the total amount of substrate converted, after 2 and $20 \mathrm{~h}$ reaction, obtained by $\mathrm{GC}$; isomers $\mathbf{1 b}, \mathbf{2 b}$ or $\mathbf{3 b}$, in each case, were the only side products of the reactions; the hydrogenation product were always less than $2 \%$.

e Molar ratio between diastereoisomeric aldehydes 1c/1d for substrate $\mathbf{1 a}, \mathbf{2 c} / \mathbf{2 d}$ for substrate $\mathbf{2 a}$ and $\mathbf{3 c} / \mathbf{3 d}$ for substrate $\mathbf{3 a}$, after $20 \mathrm{~h}$.

of a phosphorous ligand ( $\mathrm{Rh} / \mathrm{CO}$ ), a great amount of the isomerization product $\mathbf{1 b}$ was formed, since at the first stage of the reaction the isomerization of the alkene was faster than the hydroformylation. The absence of other aldehydes indicated that the trisubstituted endocyclic double bond of the isomerised product was not hydroformylated under the reactions conditions investigated. As 1a was consumed by the hydroformylation, the isomerization equilibrium 1a/1b was driven to the substrate and the overall yield for the aldehydes increased with time. It is well documented in the literature [2] that alkyl and aryl phosphines favour the hydroformylation of the substrate over its isomerization. Indeed, with the $\mathrm{PPh}_{3}$-modified catalyst, the isomerization product is formed in significantly lower amounts as compared to the unmodified system. The $\mathrm{P}\left(\mathrm{O}-\mathrm{o}^{\mathrm{t}}{ }^{\mathrm{B}} \mathrm{BuC}_{6} \mathrm{H}_{4}\right)_{3}$-modified catalyst showed an intermediate behaviour between the two other systems.

These behaviours can be better visualized on Fig. 1 in which the evolution of the reagents and products as a function of the reaction time is shown for the hydroformylation of 1a. Observing the slope of substrate consumption in Fig. 1 during the first half hour of reaction, it is possible to conclude that the initial reaction rates increase in the order: $\mathrm{Rh} / \mathrm{PPh}_{3}<\mathrm{Rh} / \mathrm{CO}<\mathrm{Rh} / \mathrm{P}\left(\mathrm{O}-\mathrm{O}^{\mathrm{t}}{ }^{\mathrm{BuC}} \mathrm{Cu}_{6} \mathrm{H}_{4}\right)_{3}$. After $20 \mathrm{~h}$, all catalysts converted more than $80 \%$ of $1 \mathrm{a}$; however, $\mathrm{Rh} / \mathrm{P}\left(\mathrm{O}-\mathrm{O}-{ }^{\mathrm{t}} \mathrm{BuC}_{6} \mathrm{H}_{4}\right)_{3}$ and $\mathrm{Rh} / \mathrm{PPh}_{3}$ presented a good chemoselectivity of ca. $90 \%$ for aldehydes, whereas $\mathrm{Rh} / \mathrm{CO}$ gave only $71 \%$ Table 3.

The best diasteroselectivity for 1c was achieved with the unmodified catalyst $\mathrm{Rh} / \mathrm{CO}(\mathbf{1 c} / \mathbf{1 d}=81 / 19)$. Since this catalytic species contains only small ligands ( $\mathrm{CO}$ and $\mathrm{H}$ ), it is sterically less hindered than in the other systems that contain more voluminous phosphorous ligands $[28,29]$. Therefore, the better performance of the unmodified system cannot be rationalized on steric grounds. The result suggests that the higher steric discrimination achieved with this system arises from a higher rate of $\beta$-elimination in the alkyl intermediate which leads to $\mathbf{1 d}$ as compared to the one that leads to the major aldehyde 1c. This would be consistent with the fact that the lowest diastereoselectivity $(66 / 34)$ is obtained with $\mathrm{Rh} / \mathrm{PPh}_{3}$, the catalyst that has produced less amount of the alkene isomer, which indicates that this is the catalyst less prone to produce $\beta$-elimination.

Substrate 2a behaves similarly to 1a with the three catalysts studied, as shown in Table 3 and Fig. 2. Nevertheless, better conversions and chemoselectivities for aldehydes were achieved after $20 \mathrm{~h}$ reaction. $\mathrm{Rh} / \mathrm{PPh}_{3}$ and $\mathrm{Rh} / \mathrm{P}\left(\mathrm{O}-\mathrm{O}^{-}{ }^{\mathrm{t}} \mathrm{BuC}_{6} \mathrm{H}_{4}\right)_{3}$ catalysts produced more than $90 \%$ conversion, with the chemoselectivity for aldehydes being higher than 95\%. Again the best diasteroselectivity $(\mathbf{2 c} / \mathbf{2 d}=74 / 26)$ was achieved with $\mathrm{Rh} / \mathrm{CO}$, although this catalyst showed lower production of aldehydes (85\%) than the P-donor modified systems.

For the study of the hydroformylation of methyl grandiflorenate 3a, Fig. 3, a mixture of this ester and methyl kaurenate 1a (77/23) was used. This was obtained from the methylation of a natural mixture of the corresponding acids with the same composition.
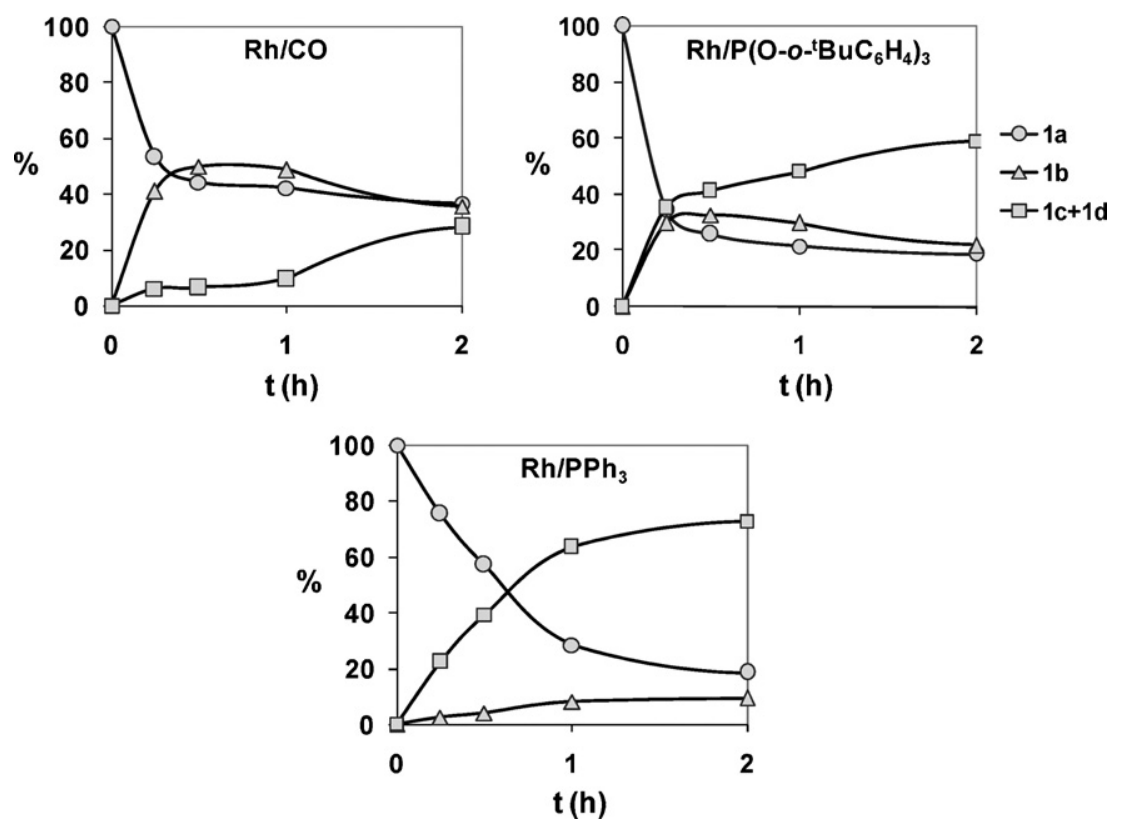

Fig. 1. Evolution of the hydroformylation of methyl kaurenate 1 a during the first $2 \mathrm{~h}$ reaction. 

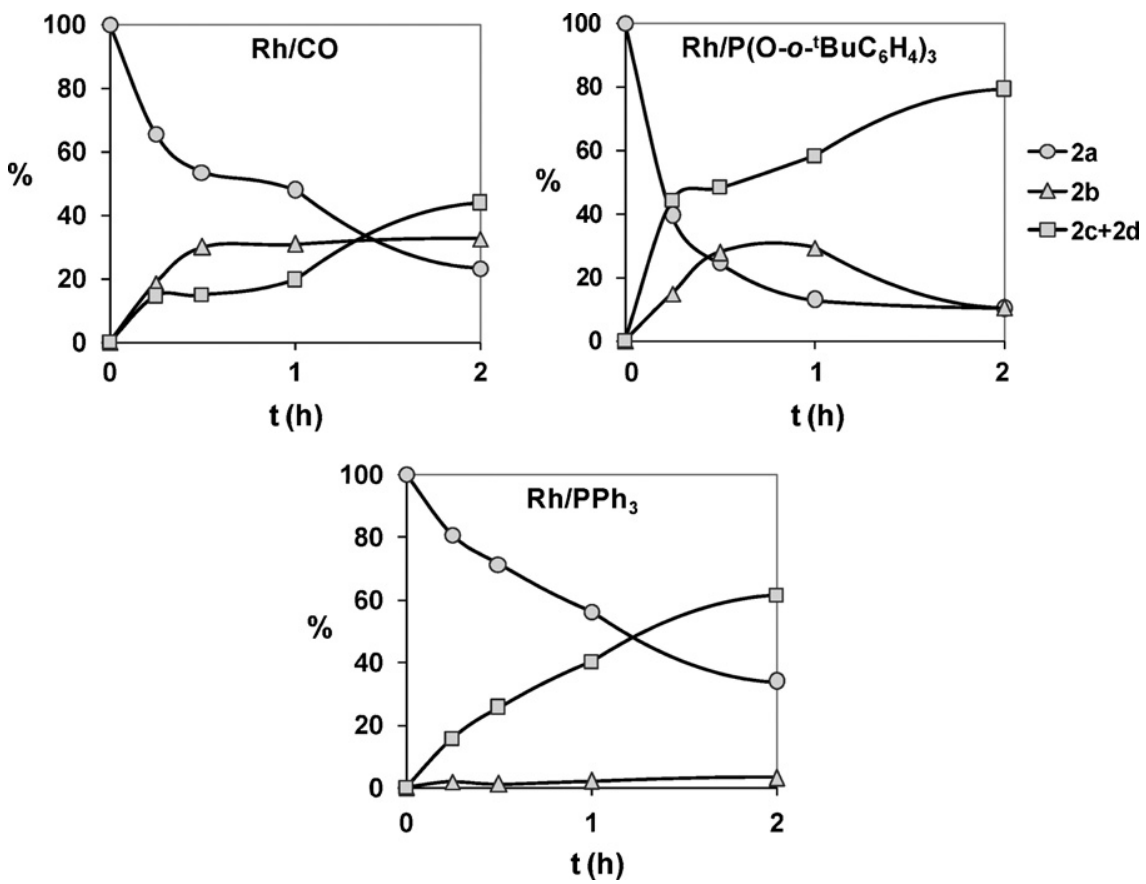

Fig. 2. Evolution of the hydroformylation of trimethylsilylkaurenol ether $2 \boldsymbol{a}$ during the first $2 \mathrm{~h}$ reaction.

Since the hydroformaylation products of 1a were already characterized, the analysis of the reaction mixtures of the hydroformylation of the methyl grandiflorenate was not troublesome.

The hydroformylation of 3a showed the best conversions and chemoselectivities among the three substrates. A nearly complete conversion was attained with $\mathrm{Rh} / \mathrm{PPh}_{3}$, and the three catalysts achieved chemoselectivities $\geq 98 \%$ for aldehydes at the end of the reaction $(20 \mathrm{~h})$. It should be noted that the unmodified system produced a significant amount of the alkene isomer $\mathbf{3 b}$ (34\% of the alkene $\mathbf{3 a}$ was converted into $\mathbf{3 b}$ after $2 \mathrm{~h}$ reaction), though, unlike the other two substrates, this isomer was almost completely converted into the aldehydes $\mathbf{3 c}$ and $\mathbf{3 d}$ via the reverse isomerization to $\mathbf{3 a}$. The endocyclic double bond introduces a greater ring strain in the substrate 3a, which is partially released by the change in hybridization from $\mathrm{sp}^{2}$ to $\mathrm{sp}^{3}$ of the $\mathrm{C} 16$ that occurs during the insertion of the alkene in the metal-hydride bond. This may give an extra driving force that could account for the higher reactivity of 3a.

The diasteroselectivities produced by the three catalysts for the substrate 3a are more closed to each other than in the case of $\mathbf{1 a}$ or $\mathbf{2 a}$, and, again, the best stereoselectivity (77/23) was achieved by the unmodified catalyst. The similarity among
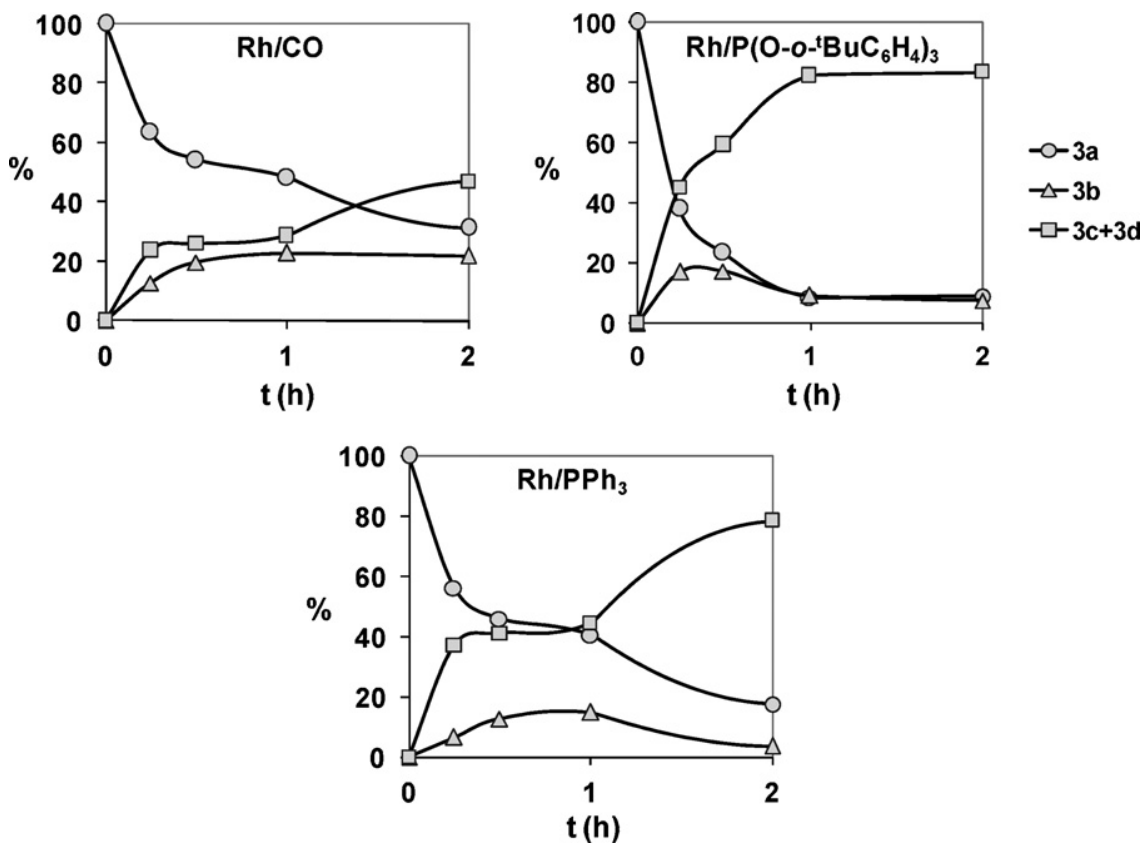

Fig. 3. Evolution of the hydroformylation of methyl grandiflorenate $3 \boldsymbol{a}$ during the first $2 \mathrm{~h}$ reaction. 
the stereoselectivities of the three catalysts in the case of $\mathbf{3 a}$ could be related with the lower tendency of metal-alkyl intermediate to produce $\beta$-elimination, as the latter would enhance the ring strain by changing the hybridization of C16 carbon from $\mathrm{sp}^{3}$ to $\mathrm{sp}^{2}$. In this case, the stereochemical output of the aldehydes would be primarily controlled by the differences in the steric hindrance of the two diasterofacial faces of the substrate.

\section{Conclusions}

The rhodium-catalyzed hydroformylation of the kaurane derivatives 1a, 2a, and 3a was achieved with high yields and selectivities under relatively mild reaction conditions. For all the catalytic systems employed, the hydroformylation was highly regioselective, giving a pair of diastereoisomeric linear aldehydes resulted from the introduction of $\mathrm{CO} / \mathrm{H}_{2}$ in the exocyclic double bond. The isomerization competition increased in the order: $\mathrm{PPh}_{3}$-modified system $<\mathrm{P}\left({ }^{\circ} \text { - }{ }^{\mathrm{t}} \mathrm{BuC}_{6} \mathrm{H}_{4}\right)_{3}$-modified system $<$ unmodified system. The isomerization products were not hydroformylated under the conditions employed and, as the substrate was consumed by the hydroformylation, the equilibrium substrate/isomer was driven to the reagent and the overall yield for the aldehydes increased with time. The diastereoselectivity is predominately controlled by the differences in the steric hindrance of the diastereotopic faces of the exocyclic double-bound and the major diastereoisomer is formed through the coordination of the olefin to the catalyst through its less hindered face. Nevertheless, the fact that the most diastereoselective catalyst is the least hindered one (unmodified system) indicates that other considerations have to be taken into account. There is a correlation between the higher diastereoselectivity and the ability of the catalytic system to promote the isomerization of the substrate. Based on this, we propose that the increased diastereoselectivity shown by the unmodified and phosphite-modified systems is due to a faster $\beta$ elimination of the metal-alkyl intermediate which leads to the minor aldehyde as compared to the one which leads to the major aldehyde. The in vitro activity against lines of carcinogenic cells of the new kaurane aldehydes and some derivatives are currently underway.

\section{Acknowledgements}

We thank to FCT-PTDC/QUI/66015/2006, CNPq, FAPEMIG MECYT (CTQ2005-09187-01) for financial support. D.S. de Melo and Y. Fonseca thanks CYTED (Project V9) for a visiting scholarship at Universidade de Coimbra and T. Fernandes thanks CYTED (Project V9) for a visiting scholarship at Universidade Federal de
Minas Gerais. A.F. Peixoto thanks FCT for a PhD grant (SFRH/BD/ 29681/2006).

\section{References}

[1] C.D. Frohning, C.W. Kohlpainter, H.-W. Bonhnen in, B. Cornils, W.A. Herrmann (Eds.), Applied Homogeneous Catalysis with Organometallic Compounds, vol. I, Wiley-VCH, 2002, pp. 31-103.

[2] E. Fernández, S. Castillón, in: P.W.N.M. van Leeuwen, C. Claver (Eds.), Rhodium Catalysed Hydroformylation, Kluwer Academic Publishers, Dordrecht, 2000, pp. 145-187.

[3] B. Breit, Top. Curr. Chem. 279 (2007) 139.

[4] H. Siegel, W. Himmele, Angew. Chem. Int. Ed. Engl. 19 (1980) 178.

[5] P.W.N.M. van Leeuwen, C.F. Roobeek, J. Organomet. Chem. 258 (1983) 342.

[6] A. van Rooy, E.N. Orij, P.C.J. Kamer, P.W.N.M. van Leeuwen, Organometallics 14 (1995) 34.

[7] N. Yoshinura, Y. Tokito, E Eur. Pat. 223103 (1987) to Kuraray.

[8] (a) A. Polo, J. Real, C. Claver, S. Castillón, J.C. Bayón, J. Chem. Soc. Chem. Commun. (1990) 600;

(b) A. Polo, C. Claver, S. Castillón, A. Ruíz, J.C. Bayón, J. Real, C. Mealli, D. Masi, Organometallics 11 (1992) 3525.

[9] E. Fernández, A. Ruiz, C. Claver, S. Castillón, A. Polo, J.F. Piniella, A. Alvarez-Larena, Organometallics 17 (1998) 2857

[10] K.F. Muilwijk, P.C.J. Kamer, P.W.N.M. van Leeuwen, J. Am. Oil Chem. Soc. 74 (1997) 223.

[11] J.G. da Silva, H.J.V. Barros, A. Balanta, A. Bolaños, M.L. Novoa, M. Reyes, R. Contreras, J.C. Bayón, E.V. Gusevskaya, E.N. dos Santos, Appl. Catal. A 326 (2007) 219.

[12] (a) Z. Freixa, M.M. Pereira, J.C. Bayón, A.M.S. Silva, J.A.R. Salvador, A.M. Beja, J.A. Paixão, M. Ramos, Tetrahedron: Asymmetry 12 (2001) 1083;

(b) A.F. Peixoto, M.M. Pereira, A.M.S. Silva, C.M. Foca, J.C. Bayón, M.J.S.M. Moreno, A.M. Beja, J.A. Paixão, M. Ramos, J. Mol. Catal. A: Chem. 275 (2007) 121.

[13] A. Usubillaga, M.C. Capra, Fitoterapia LIX (5) (1988) 383.

[14] A. Usubillaga, M. Romero, R. Aparicio, Acta Horticulturae 597 (2003) 129.

[15] E.L. Ghisalberti, Fitoterapia LXVIII 4 (1997) 303.

[16] S.Y. Ryu, J.W. Ahn, Y.N. Han, S.H. Kim, Arch. Pharmacal. Res. 19 (1996) 77

[17] H.S. Vieira, J.A. Takahashi, A.B. de Oliveira, E. Chiari, M.A.D. Boaventura, J. Braz. Chem. Soc. 13 (2002) 151

[18] S. Ogawa, K. Hosoi, N. Ikeda, M. Makino, Y. Fujimoto, T. Ida, Chem. Pharm. Bull. 55 (2007) 247

[19] T. Visbal, P. Martin, A. Mora, G.E. Delgado, A. Usubillaga, Revista Latinoamericana de Química 32 (2004) 67.

[20] J.G. Bautista, M. Monsalve, M.E. Alonso, J.L. Avila, A. Usubillaga, Ciencia 15 (2007) 248.

[21] J. Ibáñez (2004), Estudio de la composición del aceite esencial y de la resina en el ciclo vital de la Espeletia schultzii, Coespeletia moritziana, Ruilopezia atropurpurea y de un híbrido procedentes de diferentes poblaciones altitudinales, MSc. Thesis, Faculty of Sciences, University of Los Andes, Mérida, Venezuela.

[22] P. Kalck, M. Urrutigoïty, Coord. Chem. Rev. 248 (2004) 2193.

[23] A. van Rooy, J.N.H. de Bruijn, K.F. Roobeek, P.C.J. Kamer, P.W.N.M. van Leeuwen, J. Organomet. Chem. 507 (1996) 69.

[24] G. Liu, C. Li, L. Guo, M. Garland, J. Catal. 237 (2006) 67.

[25] T. Jongsma, G. Challa, P.W.N.M. van Leeuwen, J. Organomet. Chem. 421 (1991) 121.

[26] V.D. Silva, E.N. dos Santos, E.V. Gusevskaya, W.R. Rocha, J. Mol. Struct.: Theochem. 816 (2007) 109

[27] A. van Rooy, E.N. Orij, P.C.J. Kamer, F. van den Aardweg, P.W.N.M. van Leeuwen, J. Chem. Soc., Chem. Commun. 16 (1991) 1096.

[28] P.C.J. Kamer, A. van Rooy, G.C. Schoemaker, P.W.N.M. van Leeuwen, Coord. Chem. Rev. 248 (2004) 2409.

[29] M. Sparta, K.J. Borve, V.R. Jensen, J. Am. Chem. Soc. 129 (2007) 8487. 